\title{
Amino acid metabolism in the piglet: influence of level of protein and of methionine in the diet on tissue uptake and in vivo oxidation
}

\author{
BY M. J. NEWPORT*, E. R. CHAVEZ, F. D. HORNEY \\ AND H. S. BAYLEY \\ Departments of Nutrition and Clinical Studies, \\ University of Guelph, Guelph, Ontario $N_{\mathrm{I}} G_{2} W_{\mathrm{I}}$, Canada
}

(Received 6 October 1975 - Accepted I9 December 1975)

\begin{abstract}
1. ${ }^{14} \mathrm{C}$-labelled lysine, glutamic acid and methionine were each administered as single infusions through catheters in the jugular veins of pigs between 28 and $42 \mathrm{~d}$ old, receiving either a low-protein (LP) (140 g protein $/ \mathrm{kg})$, or a high-protein (HP) $(200 \mathrm{~g}$ protein $/ \mathrm{kg})$ diet. The pigs received $40 \mathrm{~g}$ diet $/ \mathrm{kg}$ body-weight per $\mathrm{d}$.

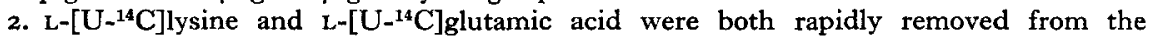
plasma; 3 min after completion of the infusion less than $10 \%$ of the activity from the $\left[{ }^{14} \mathrm{C}\right]$ lysine, and between 10 and $20 \%$ of the activity from the $\left[{ }^{14} \mathrm{C}\right]$ glutamic acid remained in the plasma.

3. In pigs killed $15 \mathrm{~min}$ after infusion of either $\left[{ }^{14} \mathrm{C}\right]$ lysine or $\left[{ }^{14} \mathrm{C}\right]$ glutamic acid $26 \%$ of the activity from the dose of lysine was in the liver of those receiving the LP diet, whereas the corresponding value was only $16 \%$ for those which had received the HP diet. The uptake of activity from $\left[{ }^{14} \mathrm{C}\right]$ glutamic acid by the liver was unaffected by the level of protein in the diet. More activity from $\left[{ }^{14} \mathrm{C}\right]$ lysine than from $\left[{ }^{14} \mathrm{C}\right]$ glutamic acid was recovered in the spleen, heart and brain.

4. The recovery of the activity from $\left[{ }^{14} \mathrm{C}\right]$ lysine as ${ }^{14} \mathrm{CO}_{2}$ in the $6 \mathrm{~h}$ after the infusion of the dose was lower for the pigs on the LP diet $(2.7 \%)$ than for those on the HP diet $(4.8 \%)$. The corresponding values for $\left[{ }^{14} \mathrm{C}\right]$ glutamic acid infusion were 34 and $52 \%$ respectively.

5. Supplementing the LP diet with five successive increments of $\mathrm{I} \cdot 5 \mathrm{~g}$ DL-methionine/kg resulted in an increase from 8 to $17 \%$ dose in the recovery of activity as ${ }^{14} \mathrm{CO}_{2}$ from a dose of $\mathrm{L}-\left[\mathrm{I}-{ }^{14} \mathrm{C}\right]$ methionine, whereas with the same supplementation of the $\mathrm{HP}$ diet the recovery increased from 8 to $24 \%$ dose.
\end{abstract}

The growing pig which is receiving a well-balanced diet uses most of the absorbed amino acids for protein synthesis, and the excess is deaminated. The carbon moieties enter the general pool of metabolic fuels, and are either stored as fat or are oxidized. Increasing the supply of a particular amino acid above that required for protein synthesis for an animal on a given dietary regimen will lead to an increase in the amount being oxidized. Brookes, Owens \& Garrigus (1972) used this approach to estimate the lysine requirement of the growing rat and sheep (Brookes, Owens, Brown \& Garrigus, 1973). The only report of amino acid oxidation in the pig was made by Cunningham (1967), who measured the time-course of elimination of ${ }^{14} \mathrm{CO}_{2}$ after the administration of a dose of $\left[{ }^{14} \mathrm{C}\right]$ valine.

The objective of the experiments to be described was to study the fate of a nonessential amino acid, glutamic acid, and two essential amino acids, lysine and methionine, in young pigs which were receiving diets containing either low or high levels

* Present address: National Institute for Research in Dairying, Shinfield, Reading RG2 9AT. 
Table 1. Composition $(\mathrm{g} / \mathrm{kg})$ of the experimental diets given to pigs

\begin{tabular}{|c|c|c|}
\hline Ingredient & Low-protein & High-protein \\
\hline Maize starch* & 565 & 465 \\
\hline Soya-bean-protein isolate $+(700 \mathrm{~g}$ protein $/ \mathrm{kg}$ ) & 260 & 360 \\
\hline Cellulose $f$ & 100 & Ioo \\
\hline Maize oil & 20 & 20 \\
\hline Limestone $(380 \mathrm{~g}$ calcium $/ \mathrm{kg})$ & 8 & 8 \\
\hline Calcium phosphate (200 g Ca, $200 \mathrm{~g}$ phosphorus $/ \mathrm{kg}$ ) & 24 & 24 \\
\hline Iodized salt (sodium chloride) & 3 & 3 \\
\hline Vitamin and trace mineral mixture $\S$ & 20 & 20 \\
\hline
\end{tabular}

of protein. The ${ }^{14} \mathrm{C}$-labelled amino acids were administered as a single intravenous infusion, and the disappearance of the label from the blood was monitored. The appearance of the label in different tissues and organs was measured, and the recovery of ${ }^{14} \mathrm{C}$ as ${ }^{14} \mathrm{CO}_{2}$ from the amino acid was determined.

\section{EXPERIMENTAL}

Animals and diets

Yorkshire or Yorkshire $\times$ Landrace pigs were weaned at $21 \mathrm{~d}$ old, and transferred to the laboratory where they were kept in individual wire cages as described by Carlson \& Bayley (1970). They were allocated to one of the two diets, low-protein (LP) or high-protein (HP), described in Table I. The piglets learnt to eat the dry diet in approximately $4 \mathrm{~d}$, then they received $20 \mathrm{~g} / \mathrm{kg}$ body-weight at 09.00 and 16.00 hours each day. They received water $a d l i b$.

\section{Surgical procedure}

When the pigs were between 25 and $28 \mathrm{~d}$ old, a catheter was inserted through the jugular vein into the vena cava so that the end of the catheter was in the region of the right atrium, using a modification of the method described by Christison \& Curtin ( 1969 ). The pig was anaesthetized with 2-bromo,2-chloro-I,I,I-trifluoroethane (Somnothane; Hoechst Pharmaceuticals, Montreal, Quebec, Canada), using a facemask and vapourizer (Ohio Medical Products, Madison, Wisconsin, USA). An incision (50 $\mathrm{mm}$ long) was made between the mandible and the sternum, and an infant feeding tube (size 5, french; C. R. Bard Inc., Murray Hill, New Jersey, USA), about $300 \mathrm{~mm}$ long, was passed through the jugular vein for about $200 \mathrm{~mm}$. The catheter was tied to the vein, brought out through the incision, and held behind the ear by a collar of adhesive tape placed around the neck. The catheter was kept filled 
with heparinized saline ( $9 \mathrm{~g}$ sodium chloride/1) solution (500000 I.U. heparin/l saline). Recovery was rapid and the pigs began to eat and drink shortly after surgery.

\section{Infusion of labelled amino acids}

The following amino acids were purchased from Amersham-Searle Ltd, Don Mills, Ontario, Canada: L-[U_-14 $\mathrm{C}]$ glutamic acid $\left(3^{1} 8 \mathrm{mCi} / \mathrm{mmol}\right)$, L-[U-14 $\left.\mathrm{C}\right] \mathrm{lysine}$ $(3 \mathrm{I} 8 \mathrm{mCi} / \mathrm{mmol})$ and $\mathrm{L}-\left[\mathrm{I}^{14} \mathrm{C}\right] \mathrm{methionine}(62 \mathrm{mCi} / \mathrm{mmol})$. They were diluted to an appropriate concentration in saline. The tracer dose was infused over $10 \mathrm{~s}$ in I or $2 \mathrm{ml}$ solution at 10.00 hours ( $\mathrm{I} \mathrm{h}$ after the morning feed). The catheter was immediately flushed with heparinized saline.

\section{Blood and tissue sampling}

The removal of the label from the blood after infusion of the dose of $\left[{ }^{14} \mathrm{C}\right]$ glutamic acid or $\left[{ }^{14} \mathrm{C}\right]$ lysine was monitored in pigs which had been receiving the HP diet. Blood samples were withdrawn from the catheter into heparinized syringes at various time intervals after infusion; after each sample the catheter was flushed with heparinized saline.

In another experiment, tissue samples were obtained from pigs which had been receiving both the LP and the HP diets. They were killed by an infusion of sodium pentobarbitone (Euthansol; W. E. Saunders Ltd, London, Ontario, Canada), and the liver, kidneys, heart, spleen and brain were removed, weighed, and a sample of each frozen in liquid nitrogen. A sample of the gluteus media and longissimus dorsi muscles, and of the subcutaneous fat was removed and frozen in liquid $\mathrm{N}_{\mathbf{2}}$.

\section{Collection of expired ${ }^{14} \mathrm{CO}_{2}$}

The pig was placed in a Perspex chamber $(0.5 \times 0.45 \times 0.25 \mathrm{~m})$, the tracer dose of the amino acid was infused, and the chamber immediately sealed. Air was drawn through the chamber at $200 \mathrm{1} / \mathrm{h}$ and the $\mathrm{CO}_{2}$ was absorbed in ethanolamine-ethylene glycol monoethyl ether $(\mathrm{I}: 2, \mathrm{v} / \mathrm{v})$ in the apparatus shown in Fig. $\mathrm{I}$. The solvent mixture from the first three traps was replaced after $0.5,1,2,3,4,5$ and $6 \mathrm{~h}$. At the end of the experiment the solvent mixture in the fourth trap was removed and sampled.

The $\mathrm{CO}_{2}$ content of the air leaving the chambers was monitored using an infrared $\mathrm{CO}_{2}$ analyser (model IR2I $5 \mathrm{~A}$; Beckman Instruments, Fullerton, California, USA).

\section{Determination of radioactivity}

Samples of plasma $(0.25 \mathrm{ml})$, and of tissue $(0.2-0.5 \mathrm{~g})$ were digested in $3 \mathrm{ml}$ of a tissue solubilizer (NCS; Amersham-Searle Ltd, Don Mills, Ontario, Canada). A I ml sample of the $\mathrm{CO}_{2}$-absorbing solution was dissolved in $3 \mathrm{ml}$ tissue solubilizer. The samples were added to $\mathrm{I} 5 \mathrm{ml}$ scintillation mixture which contained $6 \mathrm{~g} \mathrm{2,5}$-diphenyloxazole and $75.3 \mathrm{~g}$ I,4-bis(5-phenyloxazol-2-yl)-benzene/ 1 toluene. The amount of radioactivity in the samples was measured using a liquid-scintillation counter (Mark I model 6860; Nuclear Chicago Corp., Des Plaines, Illinois, USA) and the 


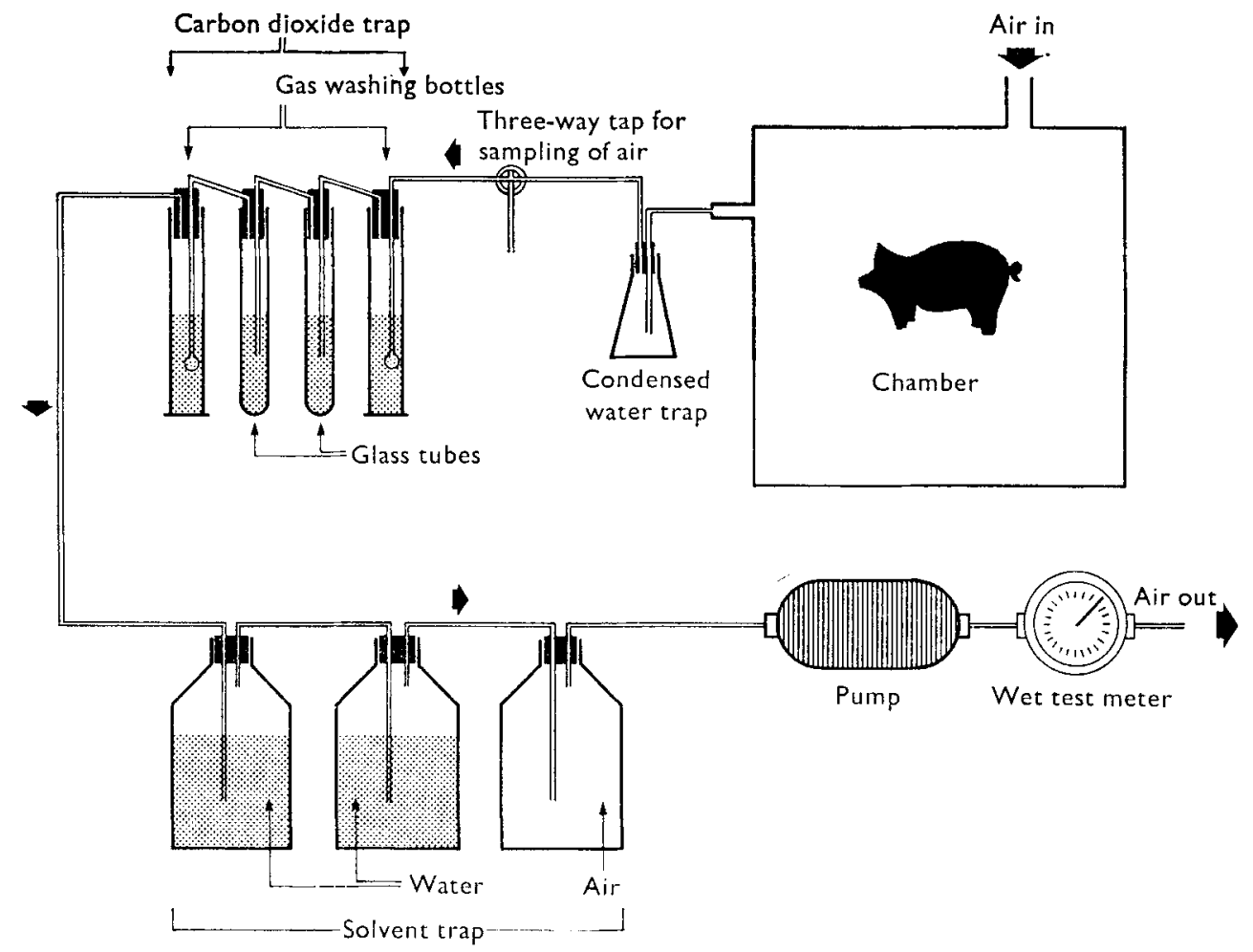

Fig. I. Apparatus used to collect ${ }^{14} \mathrm{CO}_{2}$ in ethanolamine-ethylene glycol monoethyl ether $(\mathrm{r}: 2, \mathrm{v} / \mathrm{v})$ from pigs which had received a dose of ${ }^{14} \mathrm{C}$-labelled amino acid. $\$$, Direction of flow.

values obtained were corrected for counting efficiency using the channels ratio method.

\section{Statistical analyses}

The standard error of each mean value was calculated and the statistical significance of the difference between each treatment was assessed by Student's $t$ test, as described by Steel \& Torrie (1960). The standard errors of the mean values are shown in Figs. 3-5, except where these were very small.

\section{RESULTS}

The piglets grew significantly faster on the HP diet than on the LP diet (Table 2). Daily food consumption was not affected by dietary protein level and thus food conversion efficiency was better for the HP diet.

In the first experiment $4 \mu \mathrm{Ci}\left[{ }^{14} \mathrm{C}\right]$ lysine or $3 \mu \mathrm{Ci}\left[{ }^{14} \mathrm{C}\right]$ glutamic acid was infused into pigs which were receiving the HP diet when they weighed approximately $9 \mathrm{~kg}$, and the amount of radioactivity in plasma samples was measured. Using the relationship between body-weight and plasma volume found by Talbot \& Swenson (1970), the amount of the dose remaining in the bloodstream at different intervals after the 
Table 2. Growth, food consumption and food conversion efficiency of pigs receiving a low-protein $(L P)$ or a high-protein $(H P)$ diet* for 3 weeks

(Mean values with their standard errors for five pigs/diet)

\begin{tabular}{|c|c|c|c|c|c|}
\hline & \multicolumn{4}{|c|}{ Diet } & \multirow{3}{*}{$\begin{array}{c}\text { Statistical } \\
\text { significance } \\
\text { of difference } \\
\text { between } \\
\text { mean values }\end{array}$} \\
\hline & \multicolumn{2}{|c|}{ LP } & \multicolumn{2}{|c|}{$\mathrm{HP}$} & \\
\hline & Mean & SE & Mean & $S E$ & \\
\hline $\begin{array}{l}\text { Initial body-wt at } 3 \text { weeks old }(\mathrm{kg}) \\
\text { Body-wt gain }(\mathrm{g} / \mathrm{d}) \\
\text { Food consumption }(\mathrm{g} / \mathrm{d}) \\
\text { Food conversion efficiency (g body-wt gain } / \mathrm{g}\end{array}$ & $\begin{array}{l}4.43 \\
185 \\
270 \\
0.69\end{array}$ & $\begin{array}{l}0.41 \\
8 \cdot 0 \\
18 \cdot 9 \\
\end{array}$ & $\begin{array}{l}3.98 \\
226 \\
263 \\
0.86\end{array}$ & $\begin{array}{l}0.27 \\
5.0 \\
10.5 \\
--\end{array}$ & $\begin{array}{l}\text { NS } \\
P<0 \cdot 0 \text { I } \\
\text { NS }\end{array}$ \\
\hline
\end{tabular}

NS, not significant $(P<O \cdot I)$.

* For details of diets, see Table I.

infusion was calculated, and the results are shown in Fig. $2 .\left[{ }^{14} \mathrm{C}\right]$ lysine was removed from the plasma very rapidly; only one-quarter and one-tenth of the dose remained in the plasma 0.3 and 3.0 min respectively after completion of the infusion. The results for $\left[{ }^{14} \mathrm{C}\right]$ glutamic acid indicated that this amino acid was removed from the plasma less rapidly than the $\left[{ }^{14} \mathrm{C}\right]$ lysine; over half the dose was present in the plasma 0.3 min after completion of the infusion, and after 3 min between ro and $20 \%$ of the dose remained in the plasma. After this period the rate of decrease in the amount of the dose remaining in the plasma was lower.

To study the distribution of the labelled amino acids in the tissues, a $20 \mu \mathrm{Ci}$ dose of either $\left[{ }^{14} \mathrm{C}\right]$ lysine or $\left[{ }^{14} \mathrm{C}\right]$ glutamic acid was infused into each pig which had been receiving either the $\mathrm{LP}$ or the $\mathrm{HP}$ diet. The concentration of ${ }^{14} \mathrm{C}$ from $\left[{ }^{14} \mathrm{C}\right]$ lysine was significantly higher in liver from pigs which had received the LP diet than for those which had received the $\mathrm{HP}$ diet (Table 3 ). The concentration of ${ }^{14} \mathrm{C}$ from $\left.{ }^{[14} \mathrm{C}\right]$ glutamic acid in liver from pigs which had received either the LP or the HP diets was similar to the concentration of ${ }^{14} \mathrm{C}$ from $\left[{ }^{14} \mathrm{C}\right]$ lysine in the liver of the pigs which had received the HP diet. The concentrations of ${ }^{14} \mathrm{C}$ from either of the two amino acids in any of the other tissues studied were not significantly influenced by the level of dietary protein, although there was a tendency for the concentration of ${ }^{14} \mathrm{C}$ from $\left[{ }^{14} \mathrm{C}\right]$ lysine in the kidney, spleen, heart, brain and fat to be higher for the pigs which had been receiving the LP diet, than for those which had received the HP diet. A comparison of the results for two amino acids indicated that there was a significantly higher concentration of ${ }^{14} \mathrm{C}$ from lysine than from glutamic acid in the brain and the blood.

In terms of total amount of ${ }^{14} \mathrm{C}$ in the tissues, the organ responsible for the uptake of most of the dose was the liver: significantly more lysine was taken up by the livers from the pigs which had received the LP diet than by those which had received the HP diet (Table 4). Comparisons of the amounts of ${ }^{14} \mathrm{C}$ from the two amino acids indicated that in the spleen, heart and brain there was significantly more ${ }^{14} \mathrm{C}$ from lysine than from glutamic acid.

Recovery of ${ }^{14} \mathrm{C}$ as ${ }^{14} \mathrm{CO}_{2}$ from the labelled amino acids by pigs receiving the 


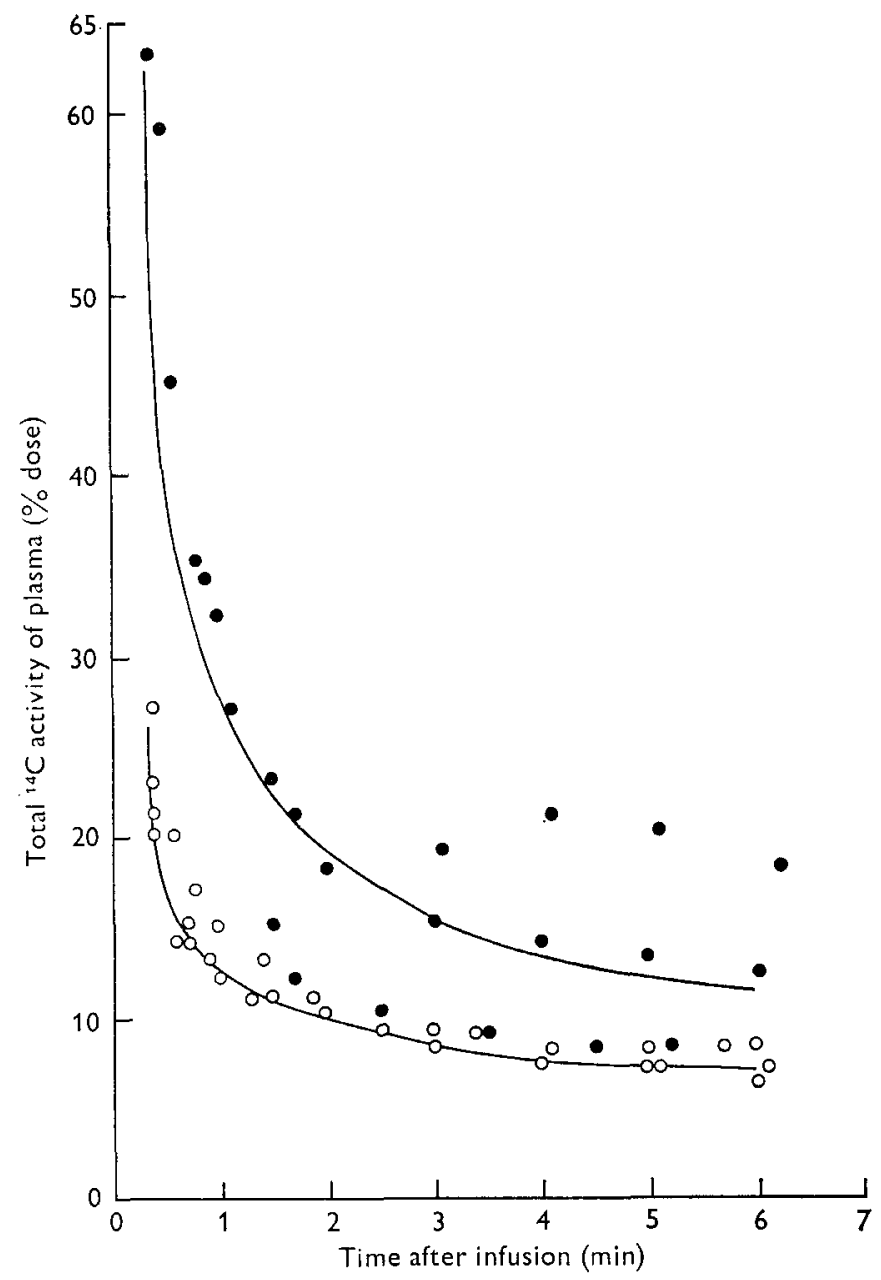

Fig. 2. Amount of ${ }^{14} \mathrm{C}(\%$ dose) recovered in plasma of pigs at intervals after infusion of a dose of $4 \mu \mathrm{Ci} \mathrm{L-}\left[\mathrm{U}-^{14} \mathrm{C}\right]$ lysine $(\mathrm{O}-\mathrm{O})$ or $\mathrm{L}-\left[\mathrm{U}-{ }^{14} \mathrm{C}\right]$ glutamic acid $(-0)$; values for four pigs for $\left[{ }^{14} \mathrm{C}\right]$ lysine infusion and for three pigs for $\left[{ }^{14} \mathrm{C}\right]$ glutamic acid infusion. Pigs were of 9-10 kg live weight and were receiving a high-protein diet (for details, see Table I).

LP or HP diet is shown in Fig. $3 \cdot{ }^{14} \mathrm{C}$ was recovered much more rapidly from $\left[{ }^{14} \mathrm{C}\right]-$ glutamic acid than from $\left[{ }^{14} \mathrm{C}\right]$ lysine. In the first $30 \mathrm{~min}$ there was no significant difference in conversion of ${ }^{14} \mathrm{C}$ from $\left[{ }^{14} \mathrm{C}\right]$ glutamic acid to ${ }^{14} \mathrm{CO}_{2}$ between pigs which had received the LP diet and those which had the HP diet. However, during the $6 \mathrm{~h}$ experimental period it became clear that the pigs given the HP diet had a more rapid loss of ${ }^{14} \mathrm{C}$ in the expired $\mathrm{CO}_{2}$ than those given the $\mathrm{LP}$ diet. The effect of dietary protein level was similar with $\left[{ }^{14} \mathrm{C}\right] l y s i n e$, although even with the HP diet less than $5 \%$ of the dose was recovered as ${ }^{14} \mathrm{CO}_{2}$, and unlike the $\left[{ }^{14} \mathrm{C}\right]$ glutamic acid curves, those for $\left.{ }^{14} \mathrm{C}\right]$ lysine showed no indication of reaching a plateau. The results for the $6 \mathrm{~h}$ recoveries of ${ }^{14} \mathrm{C}$ in $\mathrm{CO}_{2}$ (Table 5) indicated that significantly more of ${ }^{14} \mathrm{C}$ was released as $\mathrm{CO}_{2}$ from both amino acids by the pigs on the HP diet than by those on the LP diet. 
Vol. $3^{6}$

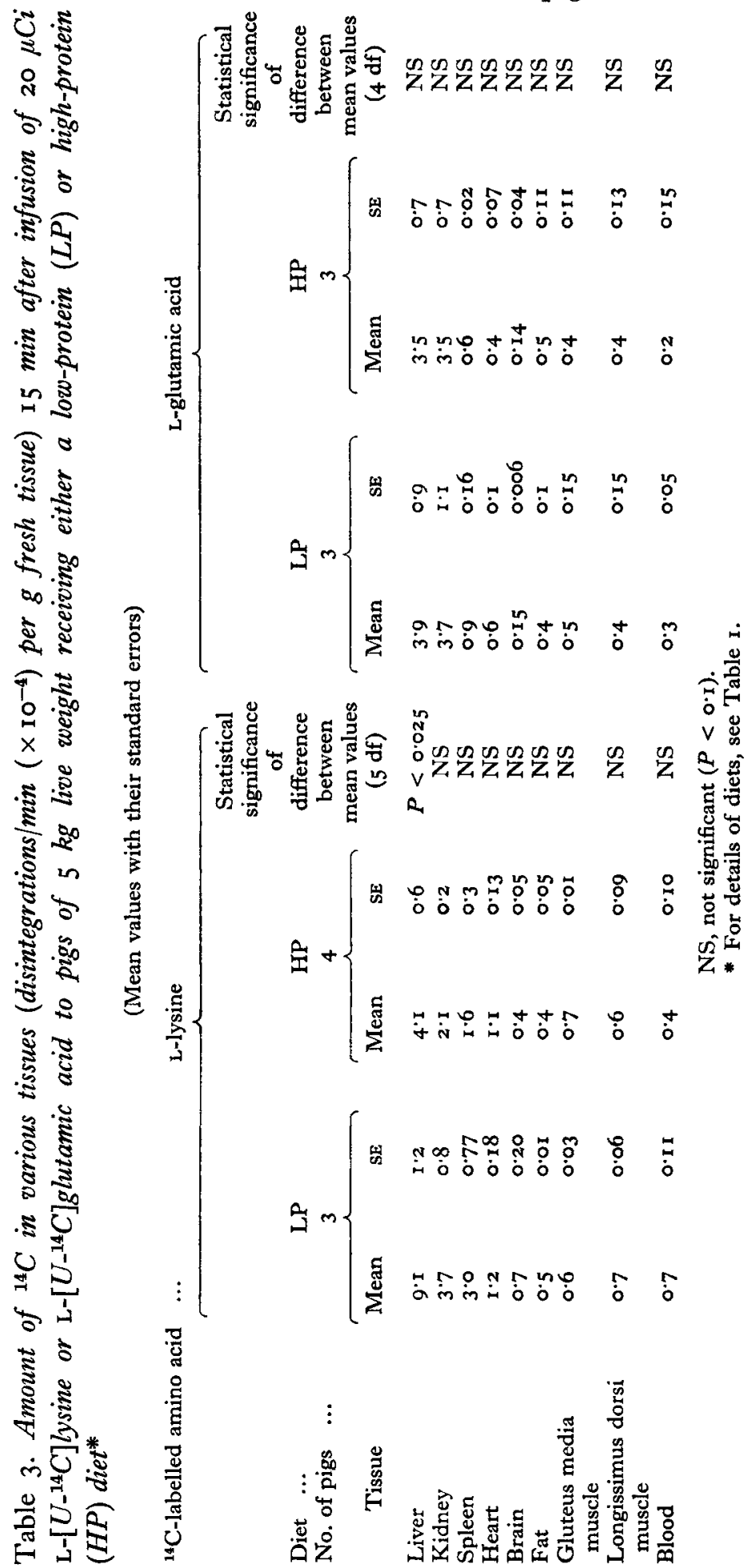




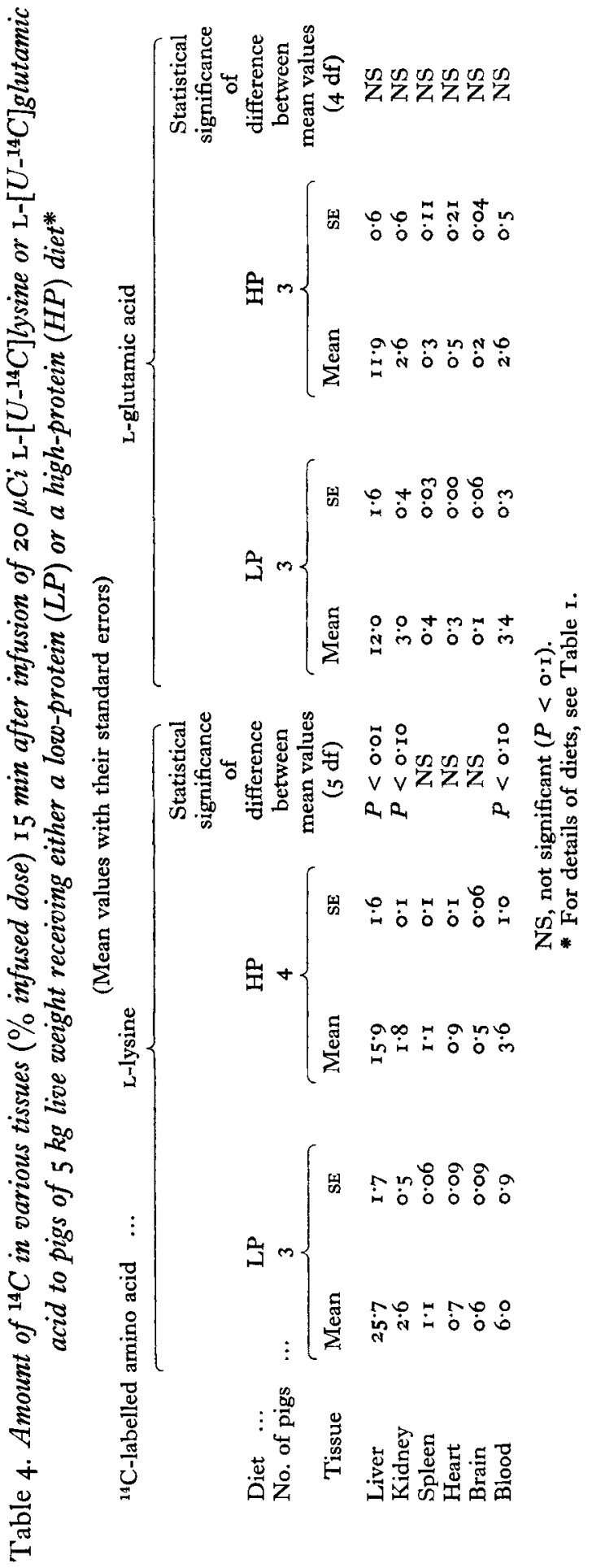




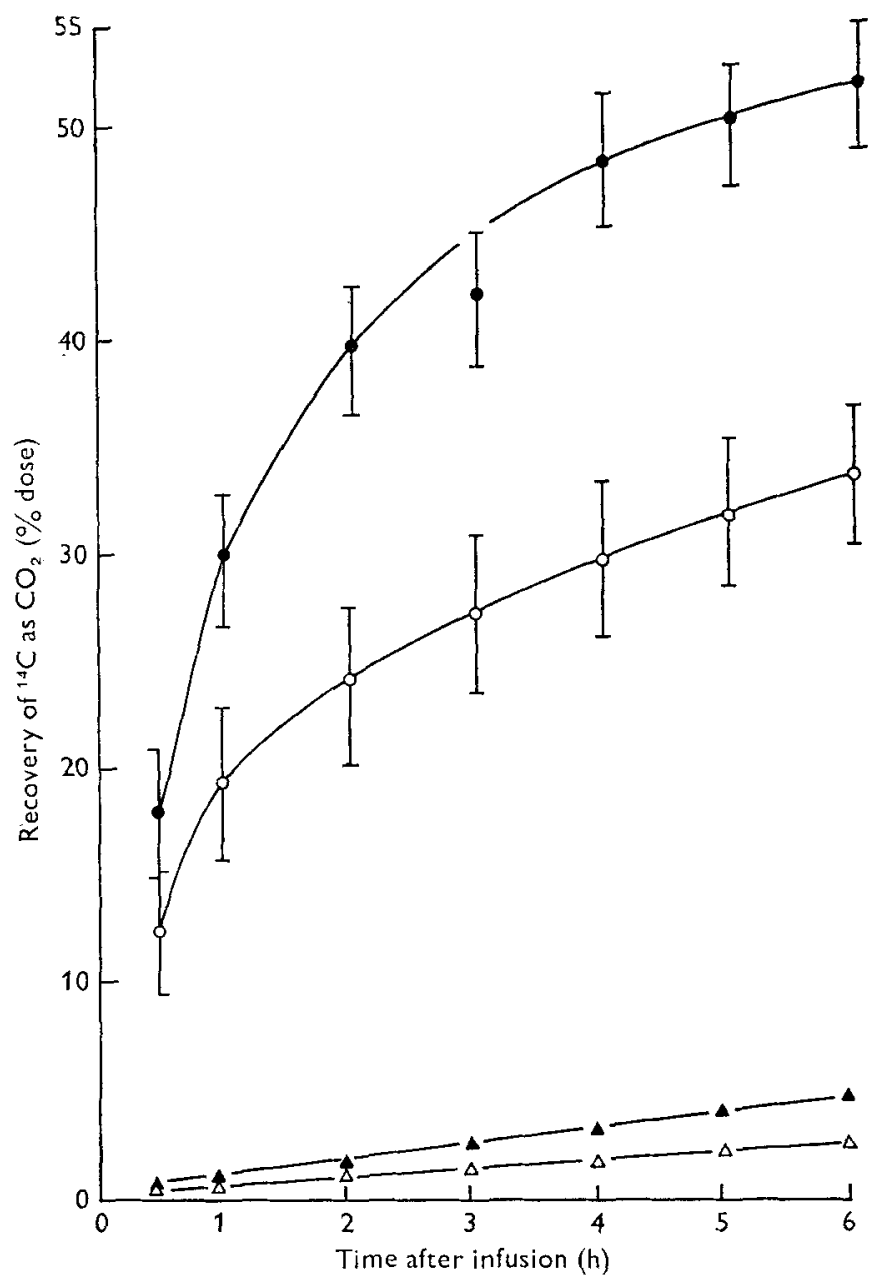

Fig. 3. Cumulative recovery of ${ }^{14} \mathrm{C}$ as ${ }^{14} \mathrm{CO}_{2}$ in $6 \mathrm{~h}$ after infusion of a dose of $0.5 \mu \mathrm{Ci} \mathrm{L}$ [U- $\left.{ }^{14} \mathrm{C}\right]$ lysine or $\mathrm{L}-\left[\mathrm{U}-{ }^{14} \mathrm{C}\right] \mathrm{glutamic}$ acid to four pigs of $7-9 \mathrm{~kg}$ live weight receiving either a low-protein (LP) or a high-protein (HP) diet (for details, see Table I). (- - ), HP diet, $\left[{ }^{14} \mathrm{C}\right]$ glutamic acid; $(\mathrm{O}-\mathrm{O}), \mathrm{LP}$ diet, $\left[{ }^{14} \mathrm{C}\right]$ glutamic acid; $(\boldsymbol{\Delta}-\mathbf{A})$, HP diet, $\left[{ }^{14} \mathrm{C}\right] l y s i n e ;$ $(\triangle-\triangle)$, HP diet, $\left[{ }^{14} \mathrm{C}\right]$ lysine. SE of each point, represented by vertical bars, is shown for $\left[{ }^{14} \mathrm{C}\right]$ glutamic acid; $\mathrm{SE}$ for $\left[{ }^{14} \mathrm{C}\right]$ lysine increased from 0.05 to $0.2 \%$ dose from the ist to the 6 th hour of the experiment.

The influence of diet on methionine metabolism was studied by supplementing the LP and HP diets with five increments of $\mathrm{I} \cdot 5 \mathrm{~g}$ DL-methionine/ $/ \mathrm{kg}$. The total sulphur amino acid levels in the unsupplemented diets were 2.4 and $3.7 \mathrm{~g} / \mathrm{kg}$ diet for the LP and HP diets respectively. The recovery of ${ }^{14} \mathrm{C}$ from a dose of $\left[{ }^{14} \mathrm{C}\right]-$ methionine in respired $\mathrm{CO}_{2}$ from pigs which had received the LP diet was markedly increased by supplementation with $7.5 \mathrm{~g}$ DL-methionine/kg diet (Fig. 4). The amounts of ${ }^{14} \mathrm{CO}_{2}$ recovered in the first $30 \mathrm{~min}$ after the dose were similar for the pigs receiving both diets. However a plateau was obtained for recovery at less than $10 \%$ dose for the pigs on the unsupplemented LP diet in the $6 \mathrm{~h}$ experiment, and for the pigs 
Table 5. Recovery (\% dose) of ${ }^{14} \mathrm{C} \mathrm{as}_{4}{ }^{14} \mathrm{CO}_{2}$ in $6 \mathrm{~h}$ after infusion of $0.5 \mu \mathrm{Ci} \mathrm{L}-\left[\mathrm{U}_{-}{ }^{14} \mathrm{C}\right]-$ lysine or $\mathrm{L}-\left[\mathrm{U}-{ }^{14} \mathrm{C}\right]$ glutamic acid to pigs of $7-9 \mathrm{~kg}$ live weight receiving either a low-protein $(L P)$ or a high-protein $(H P)$ diet*

(Mean values with their standard errors for five pigs/diet)

${ }^{14}$ C-labelled amino acid ...

Diet ...

Mean

SE

Statistical significance of dietary protein level (8 df)

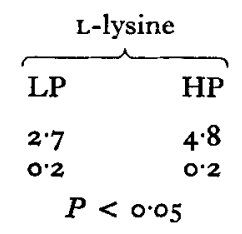

* For details of diets, see Table I.

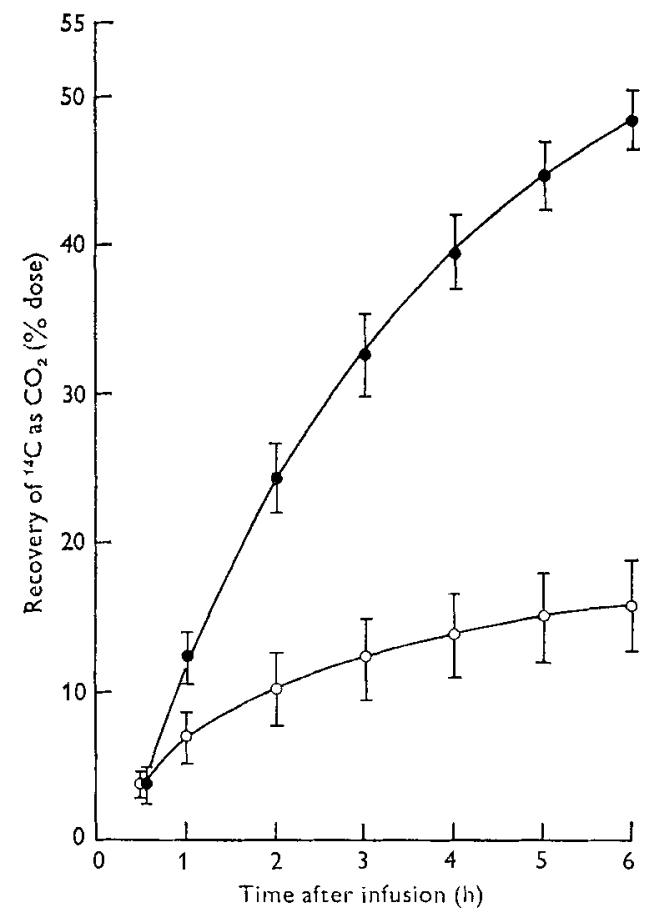

Fig. 4

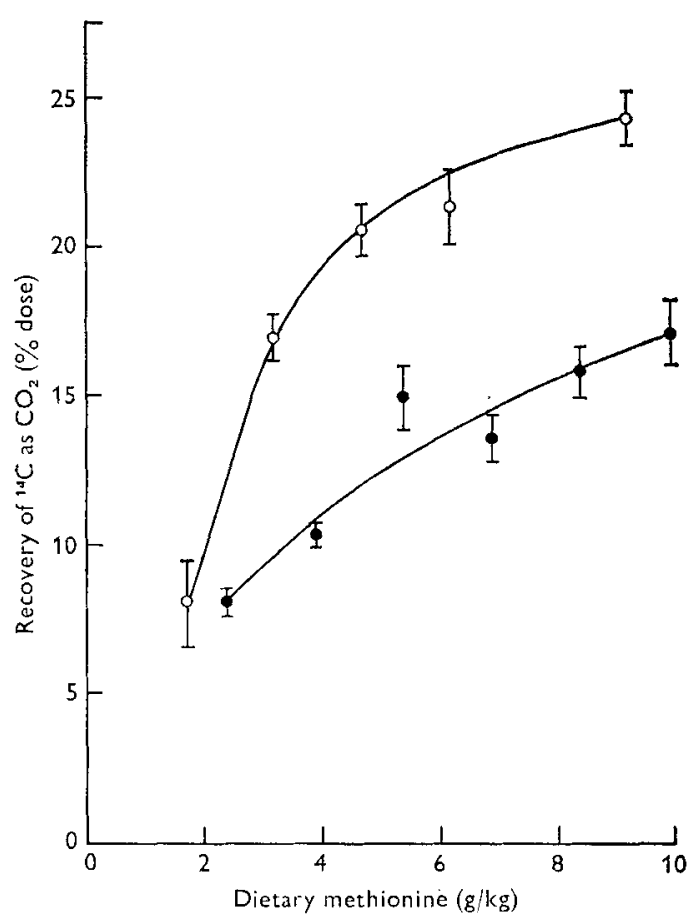

Fig. 5

Fig. 4. Cumulative recovery of ${ }^{14} \mathrm{C}$ as ${ }^{14} \mathrm{CO}_{2}$ in $6 \mathrm{~h}$ after infusion of a dose of $\mathrm{I} \mu \mathrm{Ci} \mathrm{L}-\left[\mathrm{I}-{ }^{14} \mathrm{C}\right]-$ methionine to pigs of $5-6 \mathrm{~kg}$ live weight receiving a low-protein diet (for details, see Table I) either unsupplemented (three pigs) $(\mathrm{O}-\mathrm{O})$ or supplemented with $7.5 \mathrm{~g}$ DL-methionine $/ \mathrm{kg}$ (four pigs) (-) SE of each point is represented by vertical bars.

Fig. 5. Total recovery of ${ }^{14} \mathrm{C}$ as ${ }^{14} \mathrm{CO}_{2}$ in $6 \mathrm{~h}$ after infusion of a dose of $\mathrm{I} \mu \mathrm{Ci} \mathrm{L}-\left[\mathrm{I}^{-14} \mathrm{C}\right]-$ methionine to pigs receiving either low-protein $(\mathrm{O}-\mathrm{O})$ or high-protein (-O) diets (for details, see Table I), supplemented with graded levels of DL-methionine. SE of each point is represented by vertical bars. 
which received the LP diet supplemented with $7.5 \mathrm{~g}$ methionine $/ \mathrm{kg}$, the release of ${ }^{14} \mathrm{CO}_{2}$ from the dose of $\left[{ }^{14} \mathrm{C}\right]$ methionine continued throughout the $6 \mathrm{~h}$ period.

The total amounts of ${ }^{14} \mathrm{C}$ recovered in the $6 \mathrm{~h}$ period as ${ }^{14} \mathrm{CO}_{2}$, as a percentage of the $\left[{ }^{14} \mathrm{C}\right]$ methionine dose infused, are shown in Fig. 5 for both diets. No values were obtained for the LP diet containing $7.7 \mathrm{~g}$ methionine $/ \mathrm{kg}$. Supplementing both diets with methionine increased the amount of the label recovered as $\mathrm{CO}_{2}$; however, the recoveries were higher for the LP than for the HP diet.

\section{DISCUSSION}

An infusion of tracer amounts of ${ }^{14} \mathrm{C}$-labelled lysine or glutamic acid rapidly reached an equilibrium concentration in the plasma; however, attempts to use the results to estimate 'pool size' and 'half-life' in the plasma were unsuccessful because the semilog plots of activity $v$. time were complex, indicating that a number of metabolic pools with different turnover rates were involved in the removal of ${ }^{14} \mathrm{C}$ from the plasma. Henriques, Henriques \& Neuberger (1955) made a detailed study of the specific activity of plasma glycine after the administration of $\left[{ }^{14} \mathrm{C}\right]$ glycine to the rabbit, and concluded that several reactions, each with different rates, were involved in the removal of this amino acid from the plasma. However, the results of the present experiment indicated that equilibrium between plasma and the other tissues in the distribution of ${ }^{14} \mathrm{C}$ was achieved in between 3 and $5 \mathrm{~min}$ after an infusion.

The LP diet contained Io $\mathrm{g}$ lysine $/ \mathrm{kg}$ diet, on the basis of analyses of the soya-beanprotein isolate; this was much higher than the level of 8.6 or $8.1 \mathrm{~g} / \mathrm{kg}$ which Mitchell, Becker, Jensen, Harmon \& Norton (1968), using either plasma lysine values or $\mathrm{N}$ balance as criteria, found to be required by young pigs. It is thus not surprising that increasing the level of protein in the diet, and therefore increasing the lysine level from Io to $14 \mathrm{~g} / \mathrm{kg}$ diet, resulted in a decrease in the uptake of lysine by the liver $15 \mathrm{~min}$ after the administration of the dose. A similar response was reported for leucine in plaice (Pleuronectes platessa) by Cowey (1975).

Robinson, Holmes \& Bayley (1974) found that there was a high correlation between the levels of the essential amino acids (except methionine and phenylalanine) in the blood and the protein level of the diet for pigs of $34 \mathrm{~kg}$. Mitchell et al. (1968) found that increasing the level of lysine from 9.9 to $13.9 \mathrm{~g} / \mathrm{kg}$ diet resulted in an increase in plasma lysine from $49^{\circ} \mathrm{I}$ to $75^{\circ} 7 \mu \mathrm{mol} / 1$. The greater amount of lysine in the plasma of the pigs on the HP diet in the present study would thus lead to a greater dilution of the infused dose of $\left[{ }^{14} \mathrm{C}\right]$ lysine. In contrast, the protein level in the diet had no influence on the uptake of ${ }^{14} \mathrm{C}$ from non-essential glutamic acid by any of the tissues studied.

The longer-term studies of the appearance of ${ }^{14} \mathrm{C}$ as ${ }^{14} \mathrm{CO}_{2}$ indicated that although there were no differences between the amounts of the ${ }^{14} \mathrm{C}$-labelled dose oxidized in the first $30 \mathrm{~min}$ after administration, greater amounts of ${ }^{14} \mathrm{C}$ from both amino acids were recovered as ${ }^{14} \mathrm{CO}_{2}$ from the pigs which were receiving the $\mathrm{HP}$ diet. This finding is similar to that of Yamashita \& Ashida (197I), who found that the recovery of $\left[{ }^{14} \mathrm{C}\right]$ lysine as ${ }^{14} \mathrm{CO}_{2}$ was much greater in rats which were receiving a diet containing 
an excessive level of lysine than in rats which were receiving a diet with a lower level of lysine. In the present study the ${ }^{14} \mathrm{CO}_{2}$ was being released uniformly throughout the $6 \mathrm{~h}$ experiment and so the recoveries of $5 \%$ dose or less are minimal, and continuation of the experiment for a longer period would have resulted in higher recoveries from $\left[{ }^{14} \mathrm{C}\right]$ lysine In contrast the recoveries of the label from $\left[{ }^{14} \mathrm{C}\right]$ glutamic acid appeared to reach a plateau after a slightly longer period than the $6 \mathrm{~h}$ of the experiment. The plateau was higher for the HP than for the LP diet, indicating that dietary protein level does influence the rate at which $\left[{ }^{14} \mathrm{C}\right]$ glutamic acid is converted to ${ }^{14} \mathrm{CO}_{2}$.

A faster conversion of $\left[{ }^{14} \mathrm{C}\right]$ glutamic acid than $\left[{ }^{14} \mathrm{C}\right]$ lysine to ${ }^{14} \mathrm{CO}_{2}$ would be expected since deamination of the former amino acid produces an intermediate of the tricarboxylic acid cycle directly. McFarlane \& von Holt (1969) found no differences between the oxidation of non-essential amino acids (glutamic acid and alanine) in proteindepleted and normal rats, although the oxidation of $\left[{ }^{4} \mathrm{C}\right]$ leucine and $\left[{ }^{14} \mathrm{C}\right]$ phenylalanine was reduced by protein depletion. Cowey (1975) reported no significant differences in the rate of catabolism of leucine, phenylalanine and glutamic acid when comparing low-protein with high-protein diets in the plaice.

These results with lysine and glutamic acid support the proposal of Brookes et al. (1972) that the proportion of a dose of a ${ }^{14} \mathrm{C}$-labelled amino acid oxidized depended on the adequacy of the animal's intake of the amino acid in relation to its requirement; but in the present study using methionine the results indicated that this concept was an oversimplification: adding methionine to a diet increased the recovery of ${ }^{14} \mathrm{C}$ as ${ }^{14} \mathrm{CO}_{2}$ from a dose of $\left[{ }^{14} \mathrm{C}\right]$ methionine, but the relationship was very different from that found by Brookes et al. (1972) for lysine in the rat. These authors used lysine intake as the abscissa of their graphs, whereas in the present experiment the level of dietary methionine was used; however, in the former experiment the rats were allowed to feed ad lib. and in the present experiment the pigs received a fixed amount of food, so that this would not account for the difference. Additionally, more of the infused $\left[{ }^{14} \mathrm{C}\right]$ methionine was released as ${ }^{14} \mathrm{CO}_{2}$ at a given level of dietary methionine by the pigs on the LP diet than by those receiving the HP diet, suggesting that each increment of $1.5 \mathrm{~g}$ methionine $/ \mathrm{kg}$ diet produced a greater relative surplus of this amino acid on the LP diet than on the HP diet.

The results of these studies have indicated that the oxidation of $\left[{ }^{14} \mathrm{C}\right]$ lysine was increased more than that of $\left[{ }^{14} \mathrm{C}\right]$ glutamic acid by increasing the level of protein in a diet, possibly because of the irreversible degradation of the lysine. The dietary protein level was increased by increasing the level of inclusion of the soya-beanprotein concentrate, and thus the relative excess of lysine would be greater in the HP than in the LP diet, since the relative amounts of the amino acids were the same. This finding indicates the importance of dietary level and balance on the utilization of any essential amino acid.

This work was supported by the National Research Council of Canada and the Ontario Ministry of Agriculture and Food. One of us (M.J.N.) was on leave of absence from the National Institute for Research in Dairying, Shinfield, Reading, sponsored by the UK Agricultural Research Council. 


\section{REFERENCES}

Brookes, I. M., Owens, F. N., Brown, R. E. \& Garrigus, U. S. (1973). J. Anim. Sci. 36, 965.

Brookes, I. M., Owens, F. N. \& Garrigus, U. S. (1972). f. Nutr. 102, 27.

Carlson, W. E. \& Bayley, H. S. (1970). Lab. Anim. Care 20, I 156.

Christison, G. J. \& Curtin, T. M. (1969). Lab. Anim. Care 19, 259.

Cowey, C. B. (1975). Proc. Nutr. Soc. 34, 57.

Cunningham, H. M. (1967). F. Anim. Sci. 26, 1332.

Henriques, O. B., Henriques, S. B. \& Neuberger, A. (1955). Biochem. F. 60, 409.

McFarlane, I. G \& von Holt, C. (1969). Biochem. $\mathcal{~}$. I1r, 557.

Mitchell, J. R. Jr, Becker, D. E., Jensen, A. H., Harmon, B. G. \& Norton, H. W. (1968). Y. Anim. Sci. 27, 1327.

Robinson, D. W., Holmes, J. H. G. \& Bayley, H. S. (1974). Br. vet. F. 130, 36r.

Steel, R. G. D. \& Torrie, J. H. (1960). Principles and Procedures of Statistics. New York: McGraw Hill Book Co. Inc.

Talbot, R. B. \& Swenson, M. J. (1970). Am. F. Physiol. 218, I 141.

Yamashita, K. \& Ashida, K. (1971). F. Nutr. 101, 1607. 